\title{
REGULATION OF GLYCOLYTIC FLUX IN BROCHOTHRIX THERMOSPHACTA BY THE CYTOPLASMIC PH AND ADENYLATE CHARGE: AN IN VIVO NMR STUDY
}

\author{
SATYA P. SINGH* AND PETER J. ROGERS \\ Division of Science and Technology, Griffith University, Brisbane, Q 4111, Australia
}

(Received October 7, 1991)

\begin{abstract}
Changes in the concentration of inorganic phosphate $\left(\mathrm{P}_{\mathrm{i}}\right)$ sugar phosphate, phosphoenol pyruvate (PEP), the adenylate charge and $\mathrm{pH}$ were followed by ${ }^{31}$ P-NMR and assay of cell extract during glucose fermentation in Brochothrix thermosphacta. These changes provide an estimation of glycolytic flux via pyruvate kinase as opposed to cycling of PEP through the phosphotransferase system. There appears to be a strong causal relationship between the reduced $\mathrm{pH}$, the high NTP level and the apparent reduction in pyruvate kinase activity, which support the contention that synergistic effect of $\mathrm{pH}$ and ATP on pyruvate kinase is an important regulatory factor in these cells.
\end{abstract}

Brochothrix thermosphacta (formerly Microbacterium thermosphactum (22)), a Gram-positive and facultative anaerobe, is predominantly associated with the spoilage of packaged meat products $(8,9)$. Under anaerobic conditions this has limited ability to maintain energy reserves $(8)$, and on this and other taxonomic grounds it relates to streptococci $(9,22)$. To broaden the basic understanding of metabolic regulation in this organism, we have characterized carbohydrate transport (20) and focused on the regulation of certain key enzymes $(18,19,21)$. In the present study we wished to see whether the in vitro properties of pyruvate kinase (18) could account for the apparent activity of pyruvate kinase in washed cell suspensions following glucose addition and also during the subsequent onset of starvation.

\section{MATERIALS AND METHODS}

Organism and growth conditions. B. thermosphacta (ATCC 11509) was anaerobically grown at $24^{\circ} \mathrm{C}$ in half-strength medium 56 supplemented with $0.3 \%$

\footnotetext{
* Address reprint requests to: Dr. Satya P. Singh, Department of Microbiology, CBSH, Pantnagar-263145, India.
} 
yeast extract and $0.5 \%$ glucose $(8)$.

Assay of glycolytic intermediates. Cells were harvested in late exponential to early stationary growth phase and washed twice by resuspension in cold buffer ( 5 $\mathrm{mM} \mathrm{KH}{ }_{2} \mathrm{PO}_{4}, 50 \mathrm{~mm}$ MES, $100 \mathrm{~mm}$ PIPES, $200 \mathrm{~mm} \mathrm{KCl,} 2 \mathrm{~mm}$ EDTA, $5 \mathrm{~mm}$ $\mathrm{MgSO}_{4}, \mathrm{pH} 7.4$ ) and finally resuspended in the same buffer at $50 \mathrm{mg}$ dry weight of cells per ml. Glucose was added to a final concentration of $50 \mathrm{~mm}$ and the cell suspension was subsequently sampled periodically. Two methods were used to extract glycolytic intermediates. In the first, $0.5 \mathrm{ml}$ aliquots were treated with 0.2 vol of ice-cold perchloric acid (30\%) then frozen and thawed three times before pelleting the debris at $4,000 \times g$. The supernatant was neutralized with $2 \mathrm{M} \mathrm{KHCO}_{3}$, freeze-dried and finally reconstituted with $0.5 \mathrm{ml}$ of water. These extracts were assayed for glucose, lactate, ATP and ADP. For the second method, a $0.2 \mathrm{ml}$ aliquot of the cell suspension was pipetted onto a membrane filter (cellulose mixed ester filter, $0.45 \mu \mathrm{m}$ diameter) and washed with $4 \mathrm{ml}$ of ice-cold suspension buffer (12). The filter was treated with $\mathrm{CHCl}_{3}: \mathrm{CH}_{3} \mathrm{OH}(2: 1)\left(-10^{\circ} \mathrm{C}\right)$ and processed as described earlier (12). The final clarified extract was used to assay for PEP, 2PGA, 3PGA, Fru-1,6- $\mathbf{P}_{2}$, Glc-6-P, triose phosphates and $\mathbf{P}_{\mathrm{i}}$. Fru-1,6- $\mathbf{P}_{2}, \mathrm{G} 3 \mathrm{P}$, DHAP, PEP, 2PGA and 3PGA were assayed by following NADH fluorescence associated with the enzymatic reactions involving these metabolites as described by Maitra and Estabrook (13). Glc-6-P was assayed by monitoring NADPH fluorescence during the oxidation of Glc-6-P catalyzed by Glc-6-P dehydrogenase. $\mathbf{P}_{i}$ was then determined by the addition of phosphorylase and phosphoglucomutase to this mixture which allowed the free $P_{i}$ and glycogen to produce Glc-6-P which was then used as substrate (12). ATP levels were determined with the firefly luciferase assay using the Boehringer assay kit. Fluorescence measurements for the above reactions were performed on a Perkin-Elmer LS5 Luminometer.

$p H$ estimation. The intracellular $\mathrm{pH}$ was estimated from the distribution of ${ }^{14} \mathrm{C}$-DMO between the intracelular water space and the external medium (11). Cell suspensions $\left(50-70 \mathrm{mg}\right.$ dry weight cells per $\mathrm{ml}$ ) were equilibrated at $25^{\circ} \mathrm{C}$ and DMO $(0.5 \mu \mathrm{Ci} / \mathrm{ml} ; 0.5 \mathrm{~mm})$ was added at $-4 \mathrm{~min}$. At zero time, glucose was added (usually $50 \mathrm{~mm}$ ) and $0.2 \mathrm{ml}$ aliquots were removed periodically and snap frozen in Eppendorf tubes in liquid nitrogen. At the conclusion of an experiment the aliquots were centrifuged at $4{ }^{\circ} \mathrm{C}$, which allowed the cells to pellet as the suspension thawed. The pellet was resuspended by sonication in Aquasol and counted in a Packard Series 2000 scintillation counter. By using this method we could directly relate the data of the results obtained using ${ }^{31} \mathrm{P}-\mathrm{NMR}$, which relied on using thick cell suspensions. The intact cell volume and the cytoplasmic volume were estimated using ${ }^{3} \mathrm{H}_{2} \mathrm{O}(0.25 \mu \mathrm{Ci}$ per $\mathrm{ml})$ and $\left[{ }^{3} \mathrm{H}\right]$-inulin $(0.25 \mu \mathrm{Ci}$ per $\mathrm{ml})$ as the penetrant and impermeable probes. There was no change in cytoplasmic volume due to the freezing and centrifuging as opposed to cell suspensions that were not snap frozen. The cytoplasmic and the cellular volumes in the chosen buffer conditions were 1.8 $\pm 2 \mu \mathrm{l}$ and $3.9 \pm 0.3 \mu \mathrm{l}$ per mg dry weight of cells respectively (16).

${ }^{31} P$-NMR of cells. Cells were harvested and resuspended as described above. 
${ }^{31} \mathrm{P}-\mathrm{NMR}$ were performed at $80.92 \mathrm{MHz}$ using an extensively modified Bruker wide-bore $200 \mathrm{MHz}$ spectrometer and a $10 \mathrm{~mm}$ diameter probe. Free induction decays were collected in 2 min blocks with a $30^{\circ}$ pulse and repetition times of 0.34 $\mathrm{s}$ or $2 \mathrm{~s}$ for $2 \mathrm{ml}$ samples of cell suspension. Chemical shifts are quoted relative to external $85 \%$ orthophosphoric acid. To optimize signal-to-noise ratio and to follow the kinetics of glucose metabolism, spectra were normally collected with a rapid repetition time $(0.45 \mathrm{~s})$. We compared the effects of pulse angle and dealy time on signal intensity using authentic $\mathrm{P}_{\mathrm{i}}$, ATP, ADP and Fru-1,6- $\mathrm{P}_{2}$. Cytoplasmic $\mathrm{pH}$ was determined from the chemical shift of the internal $P_{i}(5,26,27)$ whose dependence on $\mathrm{pH}$ was measured by titrating cells in the presence of $80 \mu \mathrm{M} \mathrm{CCCP}$. The $\mathbf{P}_{\mathrm{i}}$ concentration was estimated by integration of the $P_{i}$ peaks and comparison with standard curves obtained from spectra of $P_{i}$ solutions of known concentration under comparabe conditions. The estimations of sugar phosphates, $\mathbf{P}_{\mathrm{i}}, \mathrm{NTP}$ and NDP concentration were also based on the integration of peak areas.

Materials. Metabolites of the Embden-Meyerhof pathway were obtained from Boehringer Mannheim. Yeast extract was purchased from Difco; nucleotides, DCCD, CCCP and PEP were from Sigma.

Abbreviations. CCCP, carbonyl cyanide $m$-chlorophenyl-hydrozone; DCCD, dicyclohexyl-carbodiimide; DMO, 5,5-dimethyl-2,4-oxiazolidinedione; Fru-1,6- $\mathrm{P}_{2}$, fructose- 1,6 -bisphosphate; Glc-6-P, glucose- 6 -phosphate; MES, 4 -morpholineethane-sulfonic acid; NDP, nucleoside-5-dihosphate; NTP, nucleoside-5'-triphosphate; NMR, nuclear magnetic resonance; PIPES, 1,4-piperazine diethane sulfonic acid; PGA, phosphoglyceric acids. All other abbreviations have their usual meanings.

\section{RESULTS}

The effects of $A T P$ and $p H$ on pyruvate kinase in vivo

Preliminary studies with $B$. thermosphacta showed that when washed cell suspensions consume glucose there is a transient alkalinization of the cytoplasm $(18,20)$. Titration with DCCD, an $\mathrm{F}_{1} \mathrm{~F}_{0}$-ATPase inhibitor, repressed the formation of a $\mathrm{pH}$ gradient across the cell membrane although the cells continued to ferment the added glucose. The effects of DCCD treatment were examined to determine whether cytoplasmic $\mathrm{pH}$ was important in the regulation of pyruvate kinase in vivo.

In washed cell suspensions there are significant amounts of 2PGA, 3PGA, PEP and hexose phosphates. The initiation of fermentation resulted in (i) the accumulation of hexose phosphates (Fig. 1a; Table 1); (ii) an increase in the ATP/ADP ratio, which lagged behind the rate of increase of the sugar phosphates (Fig. 1b); (iii) a transient increase in the cytoplasmic $\mathrm{pH}$ (Fig. 1c); (iv) an immediate fall in cytoplasmic PEP from $3 \mathrm{~mm}$ to less than $0.2 \mathrm{~mm}$ (Fig. 1d; Table 1); (v) a sharp decline in cytoplasmic $\mathrm{P}_{\mathrm{i}}$, which was inversely proportional to the rate of sugar phosphate accumulation (Fig. 1e). Comparison of Fig. 1a with 1d suggests that the residual pre-glucose PEP reserves are initially used almost exclusively for phospho- 

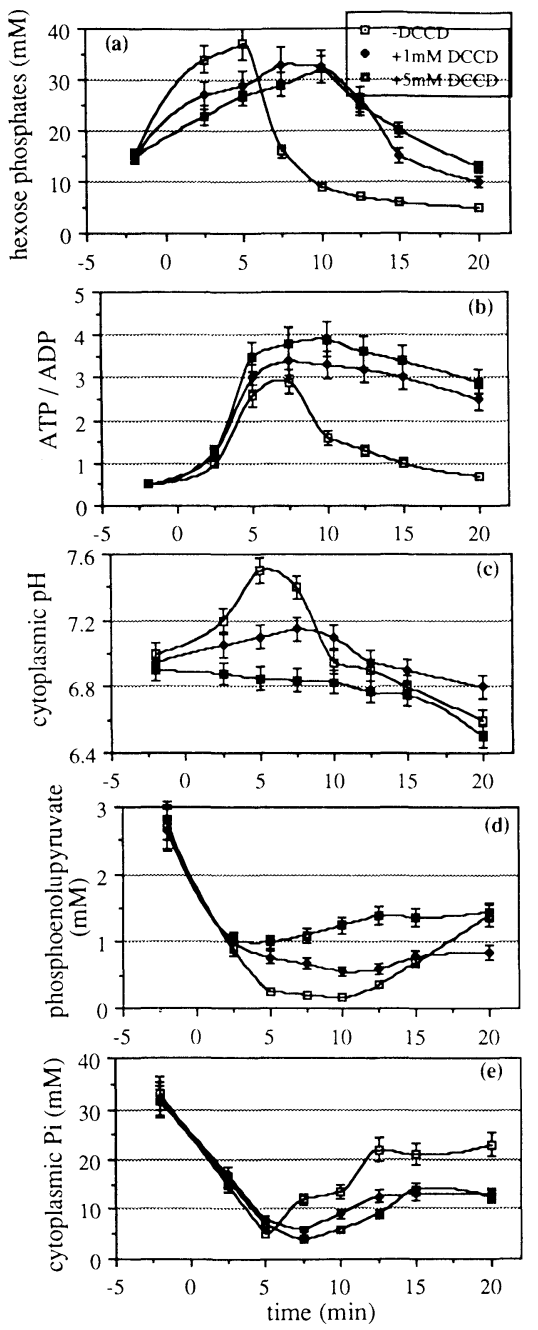

Fig. 1. The effect of DCCD titration of cells on the kinetics of metabolic changes that accompany the glucose fermentation by washed cell suspensions.

Glucose in the extracellular medium was reduced to $1 \mathrm{~mm}$ after $12 \mathrm{~min}$.

transferase-mediated glucose transport (20). ATP accumulation as mentioned above lags behind the appearance of hexose phosphates, which is consistent with the initial diversion of PEP from the glycolytic pathway to the phosphotransferase system. The rise in the ATP/ADP ratio parallels the increase in the cytoplasmic $\mathrm{pH}$ and presumably signals net ATP synthesis due to pyruvate kinase mediated substrate level phosphorylation. Stimulation of pyruvate kinase activity would be favored by the drop in cytoplasmic $\mathbf{P}_{\mathrm{i}}$, and the rise in $\mathrm{pH}$ would tend to offset the inhibitory effects of ATP. The reduction in hexose phosphates corresponds to the 
Table 1. Metabolite levels in washed cell suspensions of $B$. thermosphacta during the fermentaton of glucose.

\begin{tabular}{rccccccc}
\hline $\begin{array}{c}\text { Time } \\
(\mathrm{min})\end{array}$ & $\begin{array}{c}\text { Fru-1,6-P } \\
(\mathrm{mm})\end{array}$ & $\begin{array}{c}\text { Glc-6-P } \\
(\mathrm{mm})\end{array}$ & $\begin{array}{c}\text { Triose } \\
\text { phosphates } \\
(\mathrm{mm})\end{array}$ & $\begin{array}{c}\text { 2PGA } \\
+3 \text { PGA } \\
(\mathrm{mM})\end{array}$ & $\begin{array}{c}\text { PEP } \\
(\mathrm{mm})\end{array}$ & $\begin{array}{c}\text { ATP } \\
(\mathrm{mm})\end{array}$ & $\begin{array}{c}\text { ADP } \\
(\mathrm{mm})\end{array}$ \\
\hline-4 & 6 & 3 & 0.5 & 5 & 3.5 & 0.5 & 2 \\
+2 & 11 & 4 & 1.5 & 2 & 1.5 & 0.5 & 2 \\
+4 & 25 & 5 & 3 & 0.7 & 0.5 & 3.5 & 1.2 \\
+10 & 12 & 2 & 1 & 0.8 & 0.25 & 2.5 & 1.5 \\
+20 & 5 & 2.5 & 0.2 & 1 & 0.75 & 1.5 & 2 \\
+30 & 5 & 2.7 & 0.3 & 1 & 0.75 & 1.5 & 2 \\
+40 & 4.5 & 3 & 0.5 & 1.8 & 1.2 & 0.5 & 1.7 \\
\hline
\end{tabular}

Confidence limits for these estimates are as follows: hexose phosphates, $\pm 12 \%$, triose phosphates, $\pm 10 \%$; $2 \mathrm{PGA}+3 \mathrm{PGA}, \pm 15 \%$; PEP, $\pm 12 \%$; ATP and ADP, $\pm 12 \%$.

consumption of all the glucose and the enhanced activity of pyruvate kinase. After $30 \mathrm{~min}$, PEP levels had recovered and remained fairly constant for the next $2 \mathrm{~h}$ (not shown). However, triose phosphates drop marginally during this period, indicating that inhibition was occurring at the pyruvate kinase step (Table 1). These changes are consistent with the observed properties of the isolated pyruvate kinase. The high $P_{i}$ concentration may inhibit the enzyme despite the presence of significant amounts of Fru-1,6- $\mathrm{P}_{2}$ in the pre-glucose cells and thus account for the residual levels of PEP (18).

Titration of cells with DCCD produced significant changes in metabolite levels following glucose addition. Firstly the rate of accumulation of sugar phosphates was reduced although the transient steady state values were about the same as in the control cells. In addition, there was a much slower reduction in sugar phosphate levels in DCCD-treated cells (Fig. 1). Net ATP synthesis proceeded at much the same rate as in the controls, but the NTP/NDP ratios reached much higher values in the treated cells and remained so for a longer period than in untreated suspensions. DCCD treatment also inhibited the alkalinization of the cytoplasm (Fig. 1). The residual PEP levels during fermentation were higher in treated cells; the minimum concentration was $1 \pm 0.15 \mathrm{~mm}$, which was higher than in the controls (Fig. 1). The cytoplasmic $P_{i}$ concentration decreased by about the same margin in the DCCD-treated cells.

The slight reduction in the rate of sugar phosphate accumulation may be caused by a $\mathrm{pH}$ effect on the glucose phosphotransferase system (18). The higher NTP values are most likely due to the effect on membrane ATPase proton pumps presumably responsible for $\mathrm{pH}$ homeostasis (10).

${ }^{31} P$-NMR of cell suspensions

${ }^{31}$ P-NMR spectroscopy of thick cell suspensions of $B$. thermosphacta also demonstrated a similar pattern of change in some of the glycolytic intermediates and the cytoplasmic $\mathbf{P}_{\mathrm{i}}$ during glucose fermentation. 


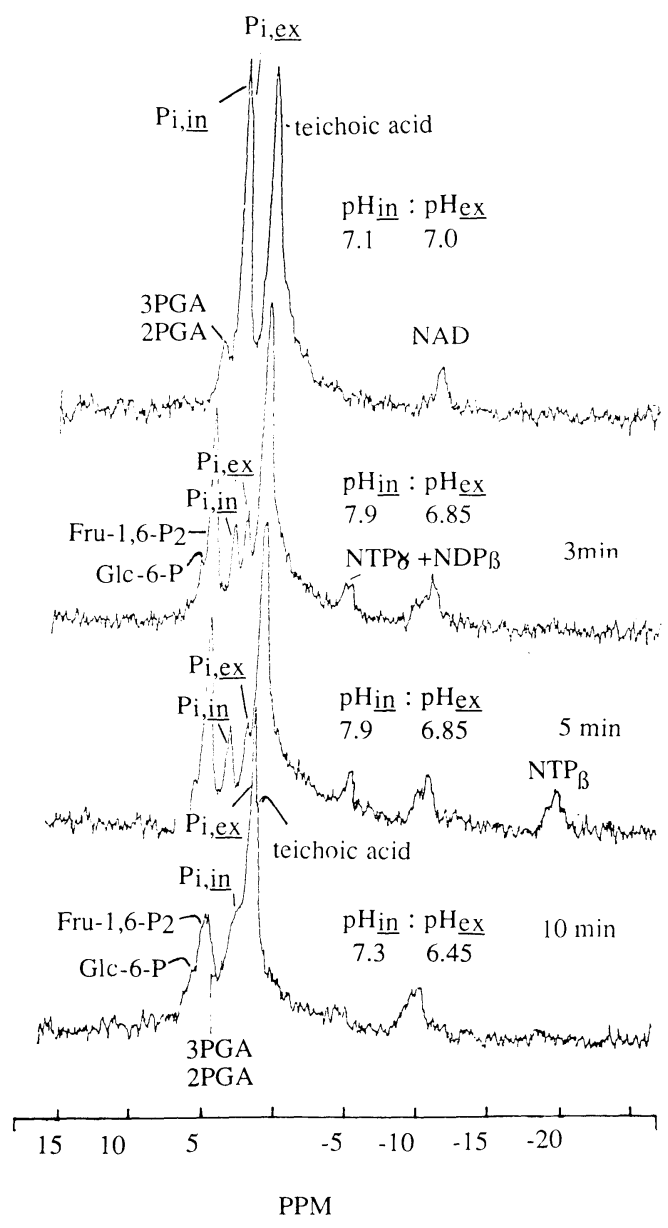

Fig. 2. Typical $80.92 \mathrm{MHz}{ }^{31} \mathrm{P}-\mathrm{NMR}$ spectra of $B$. thermosphacta cells.

Glucose $(50 \mathrm{~mm})$ was added at zero time, under anaerobic conditions; the temperature was $23^{\circ} \mathrm{C} . \mathrm{P}_{\mathrm{i}}$ ex is the extracellular $\mathrm{P}_{\mathrm{i}}$ signal and $\mathrm{P}_{\mathrm{i}} \underline{\text { in }}$ represents the cytoplasmic pool.

$\mathbf{P}_{\mathrm{i}}$, nucleoside phosphates and sugar phosphates were estimated from the ${ }^{31} \mathbf{P}$ NMR spectra of cell suspensions (Fig. 2). After glucose addition, the sugar phosphate signal (4 ppm) increased and conversely the size of the cytoplasmic $\mathbf{P}_{\mathrm{i}}$ peak diminished. After $4 \mathrm{~min}$, signals were present at $-5.5 \mathrm{ppm}$ and $-19 \mathrm{ppm}$, which were assigned to NDP + NTP and NTP respectively. The external $P_{i}$ signal moved progressively to the right as fermentation continued and the external medium became more acidic due to lactic acid efflux from the cells. This peak eventually merged with the teichoic acid signal, although before doing so it appeared as though the integral of this peak had started to increase. The 

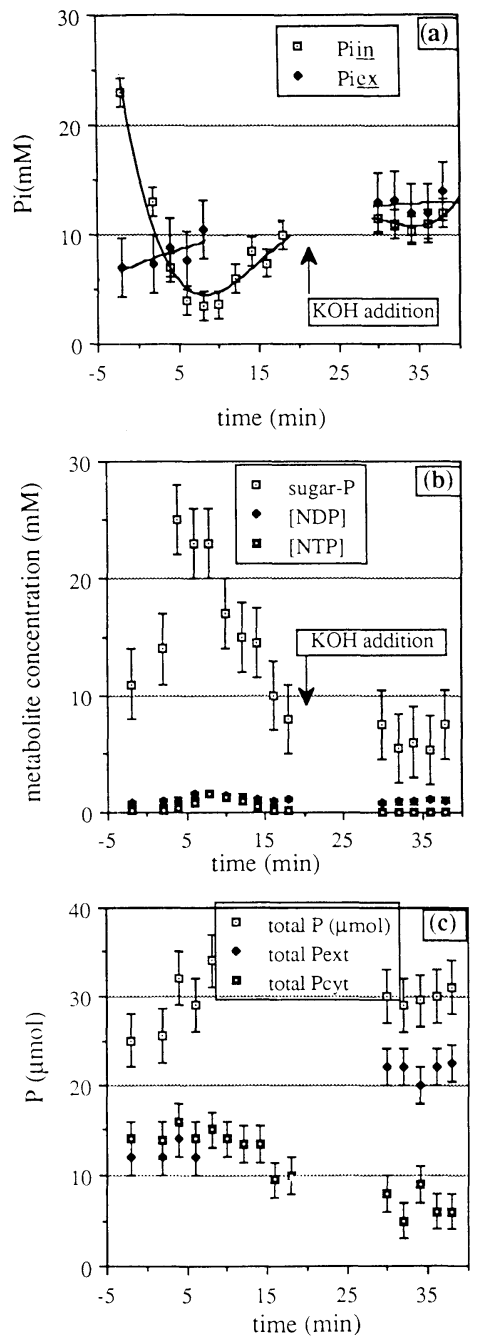

Fig. 3. Quantitation of metabolite levels from the $80.92 \mathrm{MHz}{ }^{31} \mathrm{P}-\mathrm{NMR}$ spectra of washed cell suspension of $B$. thermosphacta following glucose addition ( $50 \mathrm{~mm})$.

$\mathbf{P}_{\mathrm{i}}$ ex, extracellular $\mathrm{P}_{\mathrm{i}} ; \mathrm{P}_{\mathrm{i}}$ in, cytoplasmic $\mathrm{P}_{\mathrm{i}}$.

cytoplasmic $\mathbf{P}_{\mathrm{i}}$ signal rapidly decreased immediately after the addition of glucose, and apart from a brief shift in position to higher field strength after 2-4 min, indicative of an increase in cytoplasmic $\mathrm{pH}$, it gradually drifted down and merged with the teichoic acid peak (Fig. 2). The cytoplasmic pH was calculated from the chemical shift of the $P_{i}$ peak and is shown on Fig. 2 for representative spectra. In order to estimate $P_{i}$ in cytoplasmic and external pools after the cessation of fermentation, the $\mathrm{pH}$ of the cell suspension was readjusted to 7.2 (from below $\mathrm{pH}$ 6) with $\mathrm{KOH}$ before the spectrum was collected. 
Changes in metabolite levels were calculated on the basis of the integrated peak areas in the NMR spectra. The data summarized in Fig. 3 show large changes in the concentration of cytoplasmic $\mathrm{P}_{\mathrm{i}}$ during glucose metabolism that are reciprocated by changes in NTP and sugar phosphates. Maximum sugar phosphate accumulation $(24 \pm 2.5 \mathrm{~mm})$ preceded NTP appearance $(2-3 \mathrm{~mm}$, maximum attained). The NTP maximum coincided with the drop in cytoplasmic $\mathbf{P}_{i}$ concentration to minimum values (3-4 mM). By the end of fermentation the cytoplasmic $\mathrm{P}_{\mathrm{i}}$ level had partly recovered although at $10 \pm 3 \mathrm{~mm}$ it was considerably less than the pre-glucose value.

There was also a net reduction in total intracellular phosphorus during glucose fermentation with a corresponding increase in external $P_{i}$ (Fig. 3); 10 min after glucose addition, total phosphorus increased from $25 \pm 4$ to $34 \pm 5 \mu \mathrm{mol}(2 \mathrm{ml}$ cell suspension, as depicted in Fig. 3) and finally returned to about $30 \pm 4 \mu \mathrm{mol}$ after 30 min. This may be due to underestimation of saturation effects in pre-glucose cells or because bound $P_{i}$ is released during rapid metabolism. Nevertheless the data shows that most of the participating $\mathbf{P}$ has been accounted for.

\section{DISCUSSION}

In vitro studies $(3,4,18,23,24)$ have established that pyruvate kinase plays an important role in glycolytic regulation in group $\mathrm{N}$ streptococci and related lactic acid bacteria. There are two competing pathways from PEP to pyruvate. The pyruvate kinase catalyzed step in Brochothrix is susceptible to inhibition by ATP and $\mathrm{P}_{\mathrm{i}}$. ATP inhibition is reduced by raising $\mathrm{pH}$, and Fru-1,6- $\mathrm{P}_{2}$ serves as positive effector (18). In anaerobic cell suspensions of $B$. thermosphacta the detection of NTP corresponds with the maximum alkalinity in the cytoplast $(\mathrm{pH} 7.8)$. In the case of E. coli $(26-28), S$. faecalis $(6,7,17)$ and $S$. lactis $(25)$ the cytoplasmic $\mathrm{pH}$ during anaerobic glucose metabolism can exceed 7.5. Thus in vitro response of pyruvate kinase to $\mathrm{pH}$ values 6-8 can legitimately be extrapolated to intact bacteria. More recently, the cell viability and cessation of growth in an alkalophilic Bacillus sp. has been directly linked to acidification of cytoplasmic pH (14). Glucose addition results in the accumulation of sugar phosphates and little change in the ATP/ADP ratio as PEP is recycled for glucose uptake. Eventually the drop in $P_{i}$ concentration plus the saturating level of Fru-1,6- $\mathrm{P}_{2}$ in the cytoplasm leads to pyruvate kinase activation and the net formation of ATP by substrate level phosphorylation. This also provides substrate for the ATPase proton pump which generate a more alkaline environment. The higher $\mathrm{pH}$ would protect pyruvate kinase from ATP inhibition. The relationship between nucleotide levels and the cytoplasmic $\mathrm{pH}$ is supported by the studies with DCCD-treated cells. An interplay between cytoplasmic $\mathrm{pH}$ and ATP levels has also been described for chemostatgrown cells of $S$. cremoris (15).

Concluding the above scenario (Fig. 4), accumulation and retention of PEP, triose phosphates and haxose phosphates may be related to the need to keep 

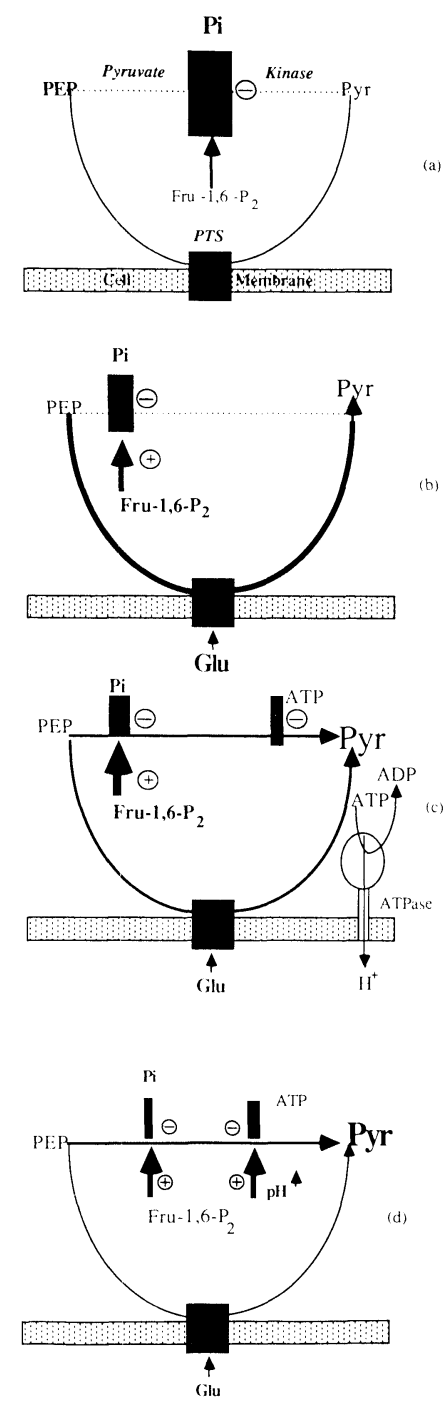

Fig. 4. Regulation of pyruvate kinase in B. thermosphacta.

(a) Washed cells suspended in buffer contain significant levels of Fru-1,6- $\mathrm{P}_{2}(>4$ $\mathrm{mm}$ ), but despite this, the high residual $P_{i}$ concentration inhibits pyruvate kinase activity and ensures that PEP is retained to prime the PTS; (b) when glucose is added this reserve is used for the initial transport of glucose into the cells. PEP subsequently generated from glycolytic activity is directed to the PTS and as a result hexose phosphates accumulate. (c) $\mathbf{P}_{\mathrm{i}}$ concentration decreases as more of the total phosphate pool is trapped. But because of the reduction in $P_{i}$ and the high level of Fru-1,6- $P_{2}$, pyruvate kinase is activated, and net synthesis of ATP takes place. As well as being a potent inhibitor of the pyruvate kinase, ATP serves as substrate for the ATPase proton pump. (d) The drop in proton concentration in the cytoplasm offsets the ATP-directed inhibition of pyruvate kinase; the Fru-1,6- $\mathrm{P}_{2}$ level is sufficiently high to guarantee high catalytic activity in the presence of reduced $\mathrm{P}_{i}$. The external glucose pool subsequently becomes depleted, the sugar phosphates diminish, $P_{i}$ once again accumulates and the situation returns to the state shown in (a) above. 
PEP-phosphotransferase system poised. Sugar phosphates and PEP may also mimic the function of creatine phosphate in animal cells and stabilize the ATP levels against sudden fluctuations of energy and demand (1). Thus pyruvate kinase may act as a choke, acting in response to a hierarchical chain of command, in which $\mathbf{P}_{\mathrm{i}}$ may play the key role. The interplay between the PEP-phosphotransferase system and pyruvate kinase revolves around the fact that PEP is a common substrate to both, and that the sugar phosphates potentiate the PK activity by reducing cytoplasmic $\mathrm{P}_{\mathrm{i}}$ concentration. The fluctuations of the glycolytic intermediate accumulation and intracellular $\mathrm{pH}$ as monitored in intact cells during fermentation by NMR, supports the physiological importance of the in vivo properties. This shows that the levels of the affectors that elicit a response in vitro, for low enzyme concentration, are similar to that of washed cells. Therefore, as quoted by Bosca and Corredor (2) for other enzymes, the importance of PK as a regulator of the glycolytic pathway will depend on the particular growth conditions, energy balance, sugar phosphate, $\mathrm{P}_{\mathrm{i}}$ and $\mathrm{pH}$. Possibility of other enzymes playing similar regulatory role is less likely as $\mathrm{P}_{\mathrm{i}}$ did not modulate phospho-fructokinase, aldolase, glyceraldehyde-3-phosphate dehydrogenase, triose phosphate isomerase and acetate kinase (results not included). However, a definite relationship between initial fluctuation of metabolites and alkalinization of the cytoplasm would need further investigation on the mechanism of $\mathrm{pH}$ homeostasis in these cells.

SPS is grateful for Griffith University Post Graduate Research Award. This work was supported by an ARGS grant to PJR. Facilities by the Dean, CBS \& H, Pantnagar during the preparation of this manuscript are acknowledged.

\section{REFERENCES}

1) Akkerman, J. W. N., Does fructose-1,6-bis phosphate reflect phosphofructokinase activity? Trends Biochem. Sci., 9, 187-188 (1985).

2) Bosca, L. and Corredor, C., Is phosphofructokinase a regulatory enzyme? Trends Biochem. Sci., 9, 372-373 (1984).

$3)$ Collins, L. B. and Thomas, T. D., Pyruvate kinase of Streptococcus lactis. J. Bacteriol., 120, 5258 (1974).

4) Crow, V. L. and Pritchard, G. G., Purification and properties of pyruvate kinase from Streptococcus lactis. Biochim. Biophys. Acta, 438, 90-101 (1976).

5) Dawson, M. J., Gadian, D. G., and Wilkie, D. R., Contraction and recovery of living muscles studied by ${ }^{31}$ P-NMR. J. Physiol., 267, 703-735 (1977).

6) Harold, F. M. and Altendorf, K., Cation transport in bacteria: $\mathrm{K}^{+}, \mathrm{Na}^{+}$and $\mathrm{H}^{+}$. Curr. Top. Membr. Transp., 5, 1-50 (1974).

7) Harold, F. M. and Kakinuma, Y., Primary and secondary transport of cations in bacteria. Ann. N. Y. Acad. Sci., 456, 375-383 (1985).

8) Hitchener, B. J., Egan, A. F., and Rogers, P. J., Energetics of Microbacterium thermosphactum in glucose limited chemostat culture. Appl. Environ. Microbiol., 37, 1047-1052 (1979).

9) Hitchener, B. J., Egan, A. F., and Rogers, P. J., Characteristics of lactic acid bacteria isolated from vacuum packaged beef. J. Appl. Bacteriol., 52, 31-37 (1982).

10) Kobayashi, H., A proton-translocating ATPase regulates $\mathrm{pH}$ of the bacterial cytoplasm. J. Biol. Chem., 260, 72-76 (1985). 
11) Krulwich, T. A. and Guffanti, A. A., Regulation of $\mathrm{pH}$ in acidophilic and alkalophilic bacteria. Methods Enzymol., 125, 352-365 (1986).

12) Mason, P. W., Carbone, D. P., Cushman, R. A., and Waggoner, A. S., The importance of inorganic phosphate in regulation of energy metabolism in Streptococcus lactis. J. Biol. Chem., 256, 1861-1866 (1981).

13) Maitra, P. K. and Estabrook, R. W., A fluorometric method for the enzymatic determination of glycolytic intermediates. Anal. Biochem., 7, 472-484 (1964).

14) Oshima, A. and Onoda, T., Acidification of intracellular $\mathrm{pH}$ results in neutral $\mathrm{pH}$ sensitive growth of an alkalophilic Bacillus sp. J. Gen. Appl. Microbiol., 36, 7-17 (1990).

15) Poolman, B., Smid, E. J., Veldkamp, H., and Konings, W. N., Bioenergetic consequences of lactose starvation for continuously cultured Streptococcus cremoris. J. Bacteriol., 169, 1460-1468 (1987).

16) Rottenberg, H., The measurement of membrane potential and $\mathrm{pH}$ in cells, organelles and vesicles. Methods Enzymol., 55, 547-569 (1979).

17) Simpson, S. J., Bendall, M. R., Egan, A. F., Vink, R., and Rogers, P. J., High field phosphorus NMR studies of the stoichiometry of lactate: Proton carrier in Streptococcus faecalis. Eur. J. Biochem., 136, 63-69 (1983).

18) Singh, S. P. and Rogers, P. J., Isolation and kinetic properties of pyruvate kinase from Brochothrix thermosphacta. Biochem. Int., 25(1), 35-45 (1991).

19) Singh, S. P. and Rogers, P. J., ${ }^{31}$ P-NMR and ${ }^{13}$ C-NMR studies on mannitol-1-phosphate formation in Brochothrix thermosphacta. Proc. 28th Annu. Conf. Assoc. Microbiologists India., Pune (1988).

20) Singh, S. P., Bishop, C. J., Vink, R., and Rogers, P. J., Regulation of the glucose phosphotransferase system in Brochothrix thermosphacta by membrane energization. J. Bacteriol., 164, 367-376 (1985).

21) Singh, S. P., Vink, R., and Rogers, P. J., Regulation of lactate dehydrogenase in Brochothrix thermosphacta. FEMS Microbiol. Lett., 22, 73-76 (1984).

22) Sneath, P. H. A. and Jones, D., Brochothrix: A new genus tentatively placed in the family lactobacillaceae. Int. J. Syst. Bacteriol., 26, 102-104 (1976).

23) Thompson, J., In vivo regulation of glycolysis and characterization of sugar: Phosphotransferase systems in Streptococcus lactis. J. Bacteriol., 136, 465-476 (1978).

24 ) Thomas, T. D., Activator specificity of pyruvate kinase from lactic streptococci. J. Bacteriol., 125, 1240-1242 (1976).

25) Thompson, J. and Torchia, D. A., Use of ${ }^{31} \mathrm{P}$-nuclear magnetic resonance and ${ }^{14} \mathrm{C}$ fluorography in studies of glycolysis and regulation of pyruvate kinase in Streptococcus lactis. J. Bacteriol., 158, 791-800 (1984).

26) Ugurbil, K., Rottenberg, H., Glynn, P., and Shulman, R. G., ${ }^{31}$ P nuclear magnetic resonance studies of the bioenergetics and glycolysis in anaerobic Escherichia coli cells. Proc. Natl. Acad. Sci. USA, 75, 2244-2248 (1978).

27) Ugurbil, K., Rottenberg, H., Glynn, P., and Shulman, R. G., Phosphorus-31 nuclear magnetic resonance studies of bioenergetics in wild type and adenosinetriphosphatase Escherichia coli cells. Biochemistry, 21, 1068-1075 (1982).

28) Vink, R., Bendall, M. R., Simpson, S. J., and Rogers, P. J., Estimation of proton to adenosine $5^{\prime}$ triphosphate stoichiometry of Escherichia coli ATPase using ${ }^{31}$ phosphorus NMR. Biochemistry, 23, 3667-3675 (1984). 